\title{
VIKOR METHOD FOR RANKING LOGISTIC VILLAGES IN TURKEY
}

\author{
Res. Assist. Dr. Emrah ÖNDER* \\ Res. Assist. Bahadır Fatih YILDIRIM*
}

\begin{abstract}
Logistics villages are defined as a specific area of all the activities carried out by a variety of logistics-related businesses. They have specific features including size, distance to city center, accessibility, proximity to road/ airport/ railway/ maritime, office and IT infrastructure etc. Ranking logistic villages is a complicated task due to the fact that various criteria or objectives must be considered in the decision making process. Also in many real world cases the criteria are not equally important for the logistic managers and government authorities. In this study, we proposed a logistic village ranking model considering both Analytic Hierarchy Process (AHP) and VIKOR (Vise Kriterijumska Optimizacija I Kompromisno Resenje) methods. Subjective and objective opinions of logistic managers/experts turn into quantitative form with AHP. VIKOR technique is used for calculating the logistic villages' ranks. The aim of this paper is to rank the 11 logistic villages in Turkey including İstanbul (Halkalı), Balıkesir (Gökköy), Eskişehir (Hasanbey), İzmit (Köseköy), Uşak, Denizli (Kaklı), Samsun (Gelemen), Mersin (Yenice), Kayseri (Boğazköprü), Konya (Kayacık) and Erzurum (Palandöken).
\end{abstract}

Keywords: Logistic Villages, Ranking, Logistic Management, Analytic Hierarchy Process, VIKOR Method, Multi Criteria Decision Making

Jel Codes: D81, C44, E22

\section{TÜRKIYYE'DEKİ LOJISTIK KÖYLERIN VIKOR YÖNTEMII ILE SIRALANDIRILMASI}

\section{ÖZ}

Lojistik köyler birçok lojistik ile ilgili aktivitelerin gerçekleştirildiği özellikli alanlar olarak tanımlanabilir. Bu köylerin büyüklüğ̈̈, şehir merkezine olan uzaklı̆̆g, erişilebilirliği, karayollarına/ havaalanlarına/ demir yollarına / limanlara olan mesafeleri, ofisler ve bilişim altyapısı vb. özellikleri önem arz etmektedir. Lojistik köylerin siralaması karar verme sürecinde birçok kriter ve amacın dikkate alınması gerektiği için karmaşık bir işlemdir. Ayrıca birçok gerçek hayat vakasında lojistik sektör yöneticileri ve kamu karar vericilerine göre kriterler eşit öneme sahip değildir. Bu çalışmada Analitik Hiyerarşi Prosesi (AHP) ve VIKOR (Vise Kriterijumska Optimizacija I Kompromisno

\footnotetext{
* Istanbul University, School of Business, Department of Quantitative Methods, emrah@istanbul.edu.tr

* Istanbul University, School of Business, Department of Quantitative Methods, bahadirf.yildirim@istanbul.edu.tr
} 
Resenje) yöntemleri birlikte kullanılarak lojistik köylerin sıralandırllmasına ilişkin model önerilmektedir. AHP lojistik sektörü yöneticileri/uzmanlarına ait sübjektif ve/veya objektif fikirlerin nicel şekilde gösterilebilmesi için kullanılmuştır. VIKOR yöntemi ise lojistik köylerin sıralandırılmasında kullanılmıştır. Bu analizde amaç Türkiye'deki 11 lojistik köyün (İstanbul-Halkall, Balıkesir-Gökköy, Eskişehir-Hasanbey, İzmit-Köseköy, Uşak, Denizli-Kaklık, Samsun-Gelemen, Mersin-Yenice, Kayseri-Boğazköprü, Konya-Kayacık ve Erzurum-Palandöken)siralanmasıdır.

Anahtar Kelimeler: Lojistik Köyler, Stralama, Lojistik Yönetimi, Analitik Hiyerarşi Prosesi, VIKOR Yöntemi, Çok Kriterli Karar Verme

Jel Kodu: D81, C44, E22

\section{INTRODUCTION}

Globalization and today's competitive environment forces companies to reduce costs. The basic condition for increasing the competition and continuity in domestic and global markets is to control costs. Locations depots have a great effect on operating cost and price. The evaluation of a logistic village location among alternative locations is a multi-criteria decision-making problem including both quantitative and qualitative criteria. All the factors should be taken into consideration because of the fact that the decisions for location selection compel a government to work under same conditions for time. If official decision makers and authorities select the wrong logistic village location, it may not have adequate access to firms, workers, vehicles, agents, and so on.

The general process for making location decisions usually is composed of the following steps (Ertuğrul ve Karakaşoğlu, 2008):

1. Decide on the criteria that will be used to evaluate location alternatives.

2. Determine the criteria that are important.

3. Develop suitable location alternatives.

4. Evaluate the alternatives and make a decision.

The aim of this paper is to identify the appropriate location providing profitability and productivity for the logistic sector. In this paper, distance and proximity data calculated via Google Maps. "Initial size of the land" and "effects on economy" data was taken from www.momentexpo.com and the working paper prepared by Aydın and Ögüt. "Cost of land" data was taken from ekonomi.haber7.com. All data is used to illustrate the logistic village evaluation procedure. We proposed a logistic village evaluation analysis using AHP and VIKOR methodologies. Subjective and objective opinions of experts turn into quantitative form with Analytic Hierarchy Process. AHP is applied to determine the relative weights of the evaluation criteria. AHP approach achieves pairwise comparisons among factors or criteria in order to prioritize them using the eigenvalue calculation. 
AHP model was represented in a questionnaire to survey experts' opinions. The relative weight of each factor in the model was calculated. In this study, Bamyaci's weights of criteria were utilized (Bamyac1, 2008). VIKOR technique is used for calculating the locations' ratings.

This paper is arranged into five sections. The second section provides an overview of existing methods and studies. The third section shows the structure of the problem in Turkey. The next section describes the proposed approach and gives information about AHP and VIKOR methodologies. In section five, an empirical study is illustrated in Turkish logistic villages. Results of the study are presented in section six. Finally, concluding remarks and discussions follow.

\section{LITERATURE REVIEW}

Several approaches have been proposed in the literature for solving the logistic/distribution center problems. Some of these methods and applications are mentioned below.

Janic and Reggiani (2002) illustrates the application of three Multiple-Criteria Decision-Making (MCDM) methods (Simple Additive Weighting, Technique for Order Preference by Similarity to the Ideal Solution and Analytic Hierarchy Process) to the problem of the selection of a new hub airport for a hypothetical European Union (EU) airline. MCDM methods are applied to a preselected set of alternative airports. Seven preselected European airports are ranked according to nine performance criteria. These criteria are "Population of airport catchment area (million)", "Per Capita Income (ECU/inhabitant)", “Airport size (millions of passengers per year)", "Minimum generalized access cost (€/passenger)", "Total airline cost of operating two-hub and spoke network (million $€$ )", "The average airport cost per service", "Airport capacity (aircraft/hour)", "Market share of the incumbent at given airport (\%)" and "Utilization of airport capacity during peaks (\%); € - EURO".

Jaržemskis's (2007) research focuses on logistics center concept and benefits for users. In this paper author presents intermodal benefit, forwarders impact, IT solutions, new transport flows due to synergy, better supply chain management, additional services, cost sharing, economies of scale, quality of the services, know-how, joint marketing impact, and benefit for growth of third-party logistics services.

In the paper of Ballis and Mavrotas (2007) three alternative designs of the logistic village layout are compared using the PROMETHEE method. The multicriteria framework consists of selecting the most meaningful criteria of evaluation and the required decision parameters. Results of their analysis reveal the preference order of the alternative designs. In this research criteria are "Total warehouse area", "Conformity with the ideal standards", "Percentage of warehouse area allocated", "Road-road cross-docking", "Rail-road cross docking", "Direct railway access", "Length of rail dock", "Travel distance from/to external road network", "Traffic density in internal road network", "Number of roadrail crossings", etc. 
Lindholm and Behrends (2012) contribute to lay the groundwork for designing strategies to overcome the challenges involved in sustainable urban logistic transport. Potentials and shortcomings in urban logistic transport planning are presented and the results show that logistic transport is increasingly important for regional competitiveness while logistic traffic is a growing threat for urban sustainability.

Cerreno et al. (2008) emphasizes in determining the feasibility of logistic villages for the NYMTC region. They investigated the NYMTC's three goals (congestion mitigation, rational and efficient land use, and economic development) regarding location selection of logistic villages.

Yanga et al. (2007) investigates distribution centers location problem under fuzzy environment via chance-constrained programming model. They integrate tabu search algorithm, genetic algorithm and fuzzy simulation algorithm to seek the approximate best solution of the model.

Awasthi, Chauhan and Goyal (2011) present a multi-criteria decision making approach for location planning for urban distribution centers under uncertainty. Their model starts with identification of potential locations, selection of evaluation criteria, than use of fuzzy theory to quantify criteria values under uncertainty and application of fuzzy TOPSIS to evaluate and select the best location for implementing an urban distribution center.

Li, Liu and Chen (2011) present a comprehensive methodology for the selection of logistic center location. Their proposed methodology consists of two parts: Axiomatic Fuzzy Set clustering method for effectively evaluate logistics center location, and TOPSIS method for selection. Their case includes fifteen regional logistics center cities and thirteen criteria including "Weather condition", "Landform condition", "Water supply", "Power supply", "Solid castoff disposal", "Communication", "Traffic", "Candidate land area", "Candidate land shape", "Candidate land circumjacent main line", "Candidate land land-value", "logistic transport" and "Fundamental construction investment".

Taniguchi et al.(1999) describe a mathematical model developed for determining the optimal size and location of public logistics terminals using queuing theory and nonlinear programming techniques for finding the best solution. They applied their model to an actual road network in the Kyoto-Osaka area in Japan.

Sirikijpanichkul and Ferreira (2006) proposed a model to solve the conflicts in intermodal logistic hub location decisions based upon the multi-objective evaluation techniques with other supporting established modules including land use allocation and transport network models; financial viability; hub user cost; and environmental and traffic impact modules.

The aim of this study is to propose a multi-criteria decision-making approach to evaluate the experts' preference orders, to examine experts' perceptions of location selection. The purposes of this study were to use Saaty's analytic hierarchy process (AHP) to investigate the factors that experts consider when choosing logistic village locations, and to derive the relative weight of each factor. 


\section{STRUCTURE OF THE LOGISTIC VILLAGE LOCATION SELECTION PROBLEM}

Target of the government and logistic sector with the new investments, is find the optimum locations of the logistic villages. Capacity of current distribution centers cannot meet the customers/firms' demand, for this reason all logistic sector actors' management are planning building a new logistic villages in order to meet growing demand. The government determined eleven logistic village locations for the new distribution centers including İstanbul (Halkalı), Balıkesir (Gökköy), Eskişehir (Hasanbey), İzmit (Köseköy), Uşak, Denizli (Kaklık), Samsun (Gelemen), Mersin (Yenice), Kayseri (Boğazköprü ), Konya (Kayacık) and Erzurum (Palandöken) (Working Paper: Aydın and Ögüt). Criteria taken in to account for logistic village ranking are as follows:

1. Initial size of the land

2. Cost of land

3. Proximity to industrial zone

4. Proximity to airport

5. Proximity to harbor

6. Proximity to railroad system

7. Proximity to highway system

8. Effects on economy

The candidate locations have advantages and disadvantages. These are shown in Table 1.

Table 1. Features of Candidate Locations

\begin{tabular}{|c|c|c|}
\hline Location & Advantages & Disadvantages \\
\hline Balıkesir (Gökköy) & Cost of land & $\begin{array}{l}\text { Initial size of the land } \\
\text { Proximity to industrial zone } \\
\text { Proximity to airport }\end{array}$ \\
\hline Denizli (Kaklık) & $\begin{array}{l}\text { Proximity to highway system } \\
\text { Effects on economy }\end{array}$ & $\begin{array}{l}\text { Proximity to harbor } \\
\text { Proximity to airport }\end{array}$ \\
\hline Erzurum (Palandöken) & $\begin{array}{l}\text { Cost of land } \\
\text { Proximity to railroad system }\end{array}$ & $\begin{array}{l}\text { Proximity to harbor } \\
\text { Effects on economy }\end{array}$ \\
\hline Eskişehir (Hasanbey) & $\begin{array}{l}\text { Proximity to railroad system } \\
\text { Proximity to airport }\end{array}$ & $\begin{array}{l}\text { Effects on economy } \\
\text { Proximity to harbor }\end{array}$ \\
\hline İstanbul (Halkalı) & $\begin{array}{l}\text { Effects on economy } \\
\text { Initial size of the land }\end{array}$ & Cost of land \\
\hline İzmit (Köseköy) & $\begin{array}{l}\text { Effects on economy } \\
\text { Initial size of the land }\end{array}$ & Cost of land \\
\hline Kayseri (Boğazköprü) & $\begin{array}{l}\text { Effects on economy } \\
\text { Proximity to highway system }\end{array}$ & $\begin{array}{l}\text { Proximity to harbor } \\
\text { Proximity to railroad system }\end{array}$ \\
\hline Konya (Kayacık) & $\begin{array}{l}\text { Proximity to railroad system } \\
\text { Proximity to airport }\end{array}$ & $\begin{array}{l}\text { Effects on economy } \\
\text { Initial size of the land } \\
\text { Proximity to harbor }\end{array}$ \\
\hline Mersin (Yenice) & $\begin{array}{l}\text { Initial size of the land } \\
\text { Proximity to highway system }\end{array}$ & Proximity to railroad system \\
\hline Samsun (Gelemen) & $\begin{array}{l}\text { Proximity to airport } \\
\text { Proximity to harbor }\end{array}$ & Initial size of the land \\
\hline
\end{tabular}




\begin{tabular}{lll}
\hline Location & Advantages & Disadvantages \\
\hline & Proximity to highway system & \\
\cline { 3 - 3 } Uşak (OSB) & Proximity to industrial zone & Proximity to harbor \\
& Cost of land & Effects on economy \\
& & Initial size of the land \\
\hline
\end{tabular}

\section{Proposed Methodology}

AHP is an effective decision making method especially when subjectivity exists and it is very suitable to solve problems where the decision criteria can be organized in a hierarchical way into subcriteria. The findings of previous studies about factors influencing experts' choice of location of logistic villages were first identified by literature review. Experts expressed or defined a ranking for the attributes in terms of importance/weights. Each experts is asked to fill "checked mark" in the 9point scale evaluation table. The AHP allows group decision making. One of the main advantages of the AHP method is the simple structure.

AHP based weights were taken from Bamyaci's research (Bamyac1, 2008). The questionnaires are answered by 42 experts (11 academicians, 13 public official logistic experts, 7 experts in customer firms, 11 experts of logistic firms). Experts are asked to compare the criteria at a given level on a pairwise basis to identify their relative precedence.

\subsection{Using AHP to analyze priorities}

AHP was developed in the 1970s by Thomas Saaty is a multi-criteria decision making (MCDM) methodology. It has been used extensively for analyzing complex decisions. The approach can be used to help decision-makers for prioritizing alternatives and determining the optimal alternative using pairwise comparison judgments (Liberatore and Nydick, 1997; Yoo and Choi, 2006). Weighting the criteria by multiple experts avoids the bias decision making and provides impartiality (Dağdeviren et al., 2009).

The AHP is a selection process that consists of following steps (Saaty, 1990; Saaty, 2008; Saaty and Vargas, 2001):

1. Define the problem and determine the criteria. Factors and related sub factors must be correlated (Lee et al., 2012)

2. Structure the decision hierarchy taking into account the goal of the decision.

3. Construct a set of all judgments in a square comparison matrix in which the set of elements is compared with itself (size $n \times n$ ) by using the fundamental scale of pair-wise comparison shown in Table 2. Assign the reciprocal value in the corresponding position in the matrix. Total number of comparison is $n \cdot(n-1) / 2$ (Lee et al., 2012) 
Table 2. The Fundamental Scale of Pair-Wise Comparison for AHP

\begin{tabular}{|c|c|c|}
\hline $\begin{array}{l}\text { Intensity of } \\
\text { Importance }\end{array}$ & Definition & Explanation \\
\hline 1 & Equal importance & Two activities have equal contribute to the objective \\
\hline 3 & Moderate importance & Experience and judgment slightly favor one activity over another \\
\hline 5 & Strong importance & Experience and judgment strongly favor one activity over another \\
\hline 7 & $\begin{array}{l}\text { Very strong on } \\
\text { demonstrated importance }\end{array}$ & An activity is favored very strongly over another \\
\hline 9 & Extreme importance & $\begin{array}{l}\text { The evidence favoring one activity over another is of the highest } \\
\text { possible order of affirmation }\end{array}$ \\
\hline $2,4,6,8$ & $\begin{array}{l}\text { For compromise between } \\
\text { the above values }\end{array}$ & $\begin{array}{l}\text { Sometimes one needs to interpolate a compromise judgment } \\
\text { numerically }\end{array}$ \\
\hline
\end{tabular}

4. Use overall or global priorities obtained from weighted values for weighting process. For synthesis of priorities obtain the principal right eigenvector and largest eigenvalue.

Matrix $A=\left(a_{i j}\right)$ is said to be consistent if $a_{i j} \cdot a_{j k}=a_{i k}$ and its principal eigenvalue $\left(\lambda_{\max }\right)$ is equal to $n$.

The general eigenvalue formulation is:

$$
\begin{gathered}
A w=\left[\begin{array}{cccc}
1 & \mathrm{w}_{1} / \mathrm{w}_{2} & \cdot & \mathrm{w}_{1} / \mathrm{w}_{\mathrm{n}} \\
\mathrm{w}_{2} / \mathrm{w}_{1} & 1 & \cdot & \mathrm{w}_{2} / \mathrm{w}_{\mathrm{n}} \\
\cdot & \cdot & \cdot & \cdot \\
\mathrm{w}_{\mathrm{n}} / \mathrm{w}_{1} & \mathrm{w}_{\mathrm{n}} / \mathrm{w}_{2} & \cdot & 1
\end{array}\right]\left[\begin{array}{l}
w_{1} \\
\cdot \\
\cdot \\
w_{n}
\end{array}\right]=n w \\
a_{i j}=w_{i} / w_{j}, \quad i, j=1,2, \ldots . n \\
A w=\lambda_{\max } w
\end{gathered}
$$

For measure consistency index $(\mathrm{CI})$ adopt the value:

$$
C I=\left(\lambda_{\max }-n\right) /(n-1)
$$


Accept the estimate of $\mathrm{w}$ if the consistency ratio $(C R)$ of $C I$ that random matrix is significant small. If $C R$ value is too high, then it means that experts' answers are not consistent (Saaty, 1990). When $C R$ value is less than 0.10 , consistency of the comparisons is appropriate (Lee et al., 2012). The $C R$ is obtained by comparing the $C I$ with an average random consistency index $(R I)$.

$$
C R=\frac{C I}{R I}
$$

The following gives the average $R I$ :

Table 3. Average RI values

\begin{tabular}{lllllllllll}
\hline $\mathrm{n}$ & 1 & 2 & 3 & 4 & 5 & 6 & 7 & 8 & 9 & 10 \\
& & & & & & & & \\
\hline $\begin{array}{l}\text { Random Consistency Index } \\
(\mathrm{RI})\end{array}$ & 0 & 0 & 0.52 & 0.89 & 1.11 & 1.25 & 1.35 & 1.40 & 1.45 & 1,49 \\
\hline
\end{tabular}

Briefly, maximized eigenvalue, $C I$ and $C R$ are found to obtain the weights of each criterion (Lee et al., 2012). Experts are asked to compare the criteria on a pair-wise basis to determine their relative importance. AHP was used in order to determine which logistic village location evaluation attributes are important and precedence order of 8 criteria, i.e., initial size of the land, cost of land, proximity to industrial zone, proximity to airport, proximity to harbor, proximity to railroad system, proximity to highway system and effects on economy.

\subsection{Using Vise Kriterijumska Optimizacija I KompromisnoResenje (VIKOR) to Rank the Alternatives}

VIKOR (Vise Kriterijumska Optimizacija I Kompromisno Resenje-a Serbian name) was first presented by Opricovic (1998) and Opricovic and Tzeng (2002), for solving multiple criteria decision making (MCDM) problems based upon the adoption of Lp-metric concept (Opricovic, 2011; Opricovic and Tzeng, 2002) VIKOR method focuses on ranking and selection from a set of alternatives in cases of conflicting criteria (Chui et al., 2013) It is a technique for multi-criteria optimization of complex systems (Opricovic and Tzeng, 2004). Assuming that each alternative is evaluated according to each criterion function, the compromise ranking could be performed by comparing the measure of closeness to the ideal alternative (Zhang and Wei, 2013). The various $J$ alternatives are denoted as $a_{1}, a_{2}, \ldots, a_{J}$. For alternative $a_{J}$, the rating of the $i$ th aspect is denoted by $f_{i j}$, i.e. $f_{i j}$ is the value of $i$ th criteria function for the alternative $a_{J} ; n$ is the number of criteria.

Developing of the VIKOR method started with the following form of Lp-metric (Opricovic and Tzeng, 2004; Opricovic and Tzeng, 2007; Tzeng et al., 2005) 


$$
L_{p, j}=\left\{\sum_{i=1}^{n}\left[w_{i} \frac{\left(f_{i}^{*}-f_{i j}\right)}{\left(f_{i}^{*}-f_{i}^{-}\right)}\right]^{p}\right\}^{\frac{1}{p}} \quad 1 \leq p \leq \infty ; j=1,2, \ldots, J
$$

Within the VIKOR method $L_{1, j}$ are used to formulate ranking measure. The solution obtained by $\min _{j} S_{j}$ is a maximum group utility, and the solution obtained by $\min _{j} R_{j}$ is with minimum individual regret of the "opponent".

The compromise solution $F^{c}$ is a feasible solution that is the "closest" to the ideal $F^{*}$, and compromise means an agreement established by mutual concessions, as is illustrated in Fig. 1 by $\Delta f_{1}=f_{1}^{*}-f_{1}^{c}$ and $\Delta f_{2}=f_{2}^{*}-f_{2}^{c}$

The compromise ranking algorithm VIKOR is conducted as follows:

Step 1. Determine the ideal $f_{i}^{*}$ and the nadir $f_{i}^{-}$values of all criteria functions $(i=1,2, \ldots, n)$ according to benefit or cost functions. If the $i$ th function represents a benefit then:

$$
f_{i}^{*}=\max _{j} f_{i j}, \quad f_{i}^{-}=\min _{j} f_{i j}
$$

If the $i$ th function represents a cost then:

$$
f_{i}^{*}=\min _{j} f_{i j}, \quad f_{i}^{-}=\max _{j} f_{i j}
$$

Step 2. Compute the values $S_{j}$ and $R_{j}, j=1,2, \ldots, J$, by the relations

$$
\begin{gathered}
S_{j}=\sum_{i=1}^{n} w_{i} \frac{\left(f_{i}^{*}-f_{i j}\right)}{\left(f_{i}^{*}-f_{i}^{-}\right)} \\
R_{j}=\max _{i}\left[w_{i} \frac{\left(f_{i}^{*}-f_{i j}\right)}{\left(f_{i}^{*}-f_{i}^{-}\right)}\right]
\end{gathered}
$$




\section{Figure 1. Ideal and Compromise Solution}

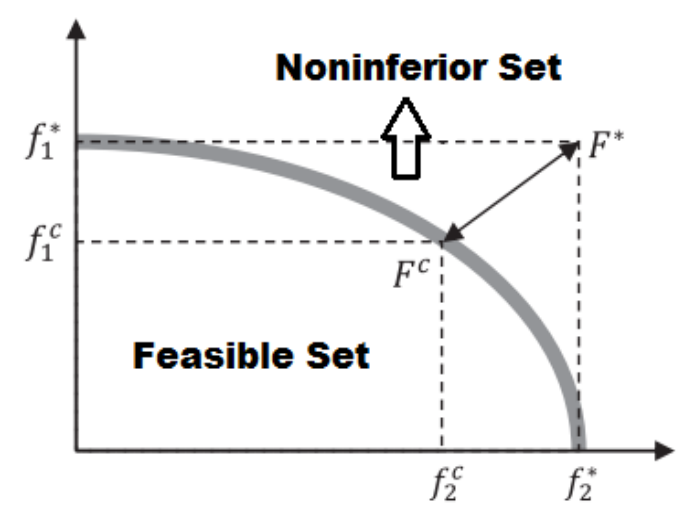

Where $w_{i}$ are the weights of criteria, expressing their relative importance.

Step 3. Compute the values $Q_{j}, j=1,2, \ldots, J$, by the relation

$$
Q_{j}=v \frac{\left(S_{j}-S^{*}\right)}{\left(S^{-}-S^{*}\right)}+(1-v) \frac{\left(R_{j}-R^{*}\right)}{\left(R^{-}-R^{*}\right)}
$$

Where

$$
\begin{array}{ll}
S^{*}=\min _{j} S_{j}, & S^{-}=\max _{j} S_{j} \\
R^{*}=\min _{j} R_{j}, & R^{-}=\max _{j} R_{j}
\end{array}
$$

and $v$ is introduced as weight for the strategy of the maximum group utility, whereas 1-v is the weight of the individual regret. Usually the value of $v$ is taken as 0.5 (Liu et al., 2013)

Step 4. Rank the alternatives, sorting by the values $S, R$ and $Q$, in decreasing order. The results are three ranking lists.

Step 5. Propose as a compromise solution the alternative $\left(a^{\prime}\right)$ which is ranked the best by the measure $Q$ (minimum) if the following two conditions are satisfies:

C1. Acceptable Advantage:

$$
Q\left(a^{\prime \prime}\right)-Q\left(a^{\prime}\right) \geq D Q
$$

Where $a^{\prime \prime}$ is the alternative with second position in the ranking list by $Q ; D Q=1 /(J-1) ; J$ is the number of alternatives. 


\section{C2. Acceptable stability in decision making:}

Alternative $a^{\prime}$ must also be the best ranked by $S$ or/and $R$. This compromise solution is stable within a decision making process, which could be "voting by majority rule" (when $v>0.5$ is needed), or "by consensus" $v \approx 0.5$, or "with veto" $(v<0.5)$. Here, $v$ is the weight of the decision making strategy "the majority of criteria" (or "the maximum group utility").

If one of the conditions is not satisfied, then a set of compromise solutions is proposed, which consists of:

- Alternatives $a^{\prime}$ and $a^{\prime \prime}$ if only condition $\mathbf{C 2}$ is not satisfied, or

- Alternatives $a^{\prime}, a^{\prime \prime}, \ldots, a^{(M)}$ if condition $\mathbf{C} 1$ is not satisfied; and $a^{(M)}$ is determined by the relation $Q\left(a^{(M)}\right)-Q\left(a^{\prime}\right)<D Q$ for maximum $M$ (the positions of these alternatives are "in closeness").

The best alternative, ranked by $Q$, is the one with the minimum value of $Q$. The main ranking result is the compromise ranking list of alternatives, and the compromise solution with the "advantage rate". Ranking by VIKOR may be performed with different values of criteria weights on proposed compromise solution. VIKOR is effective tool in multi criteria decision making, particularly in a situation where the decision maker is not able, or does not know to express his/her preference at the beginning of system design. The obtained compromise solution could be accepted by the decision makers because it provides a maximum "group utility". The compromise solutions could be the basis for the negotiations, involving the decision makers' preference by criteria weights.

VIKOR technique is widely used in many fields including marketing (Tsai et al., 2011; Wang and Tzeng, 2012); material selection (Cavallini et al., 2013; Jahan et al., 2011; Girubha and Vinodh, 2012; Liu et al., 2013); vendor/supplier selection (Hsu et al., 2012; Shemshadi et al., 2011; Sanayei et al., 2010); project selection (Cristobal, 2011; Chen and Wang, 2009); company selection (Yücenur and Demirel, 2012); service quality evaluation (Kuo and Liang, 2011); financial performance evaluation (Yalçın et al., 2012); tourism policy improvement (Liu et al., 2012; Liu et al., 2013); location selection (Tzeng et al., 2002) etc. One of the advantages of VIKOR is that VIKOR method proposes a compromise solution with an advantage rate (Opricovic and Tzeng, 2004). Also pair-wise comparisons are avoided.

\subsection{Combining AHP and VIKOR to Determine the Rank of Alternatives}

In analyzing the data, Analytical Hierarchy Process (AHP) and VIKOR methodologies are used for the outranking of logistic village alternatives. Figure 2 shows the steps of the proposed method. 
Figure 2. Steps of proposed method

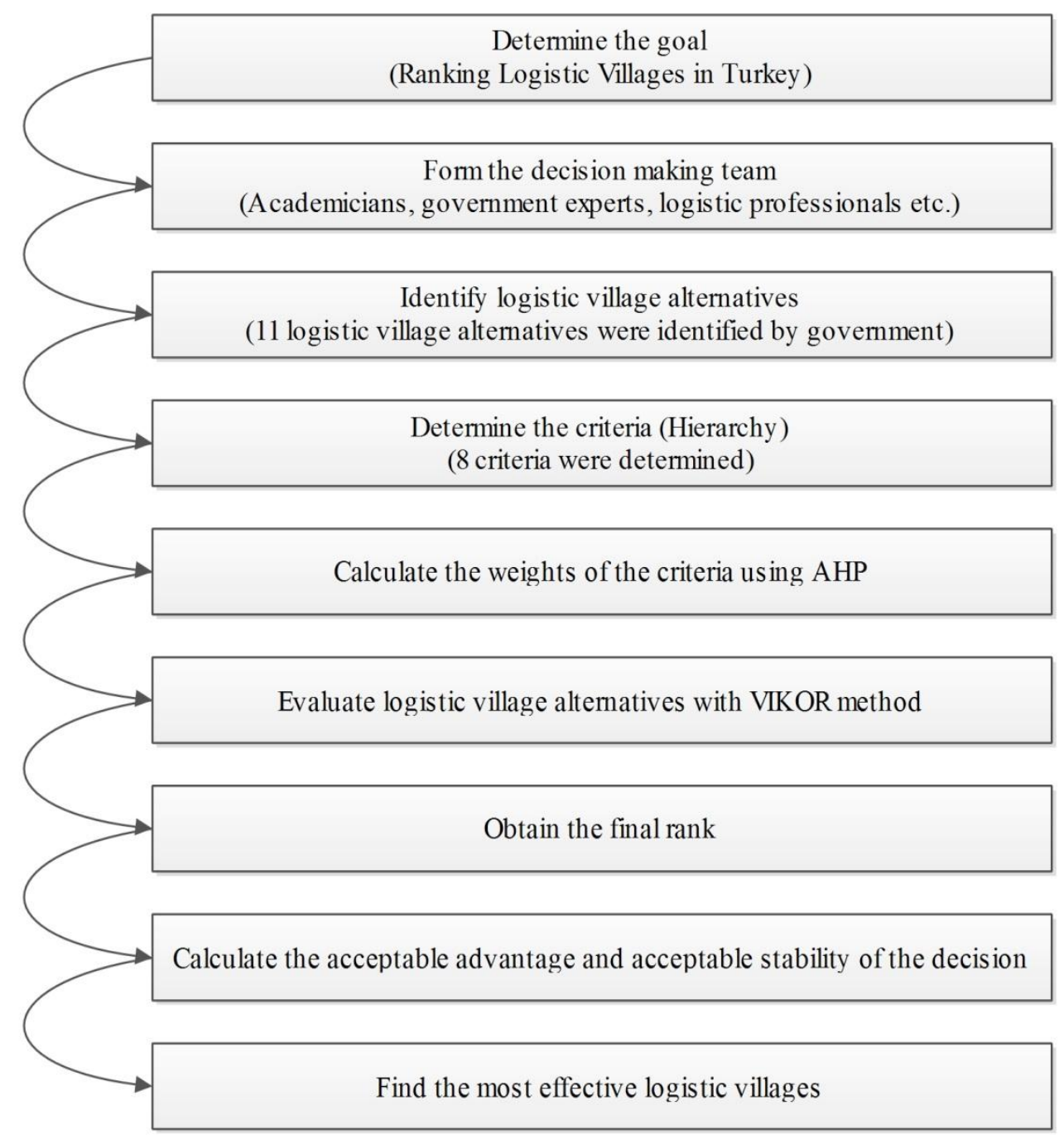

\subsection{Solving Case Problem}

To apply proposed method a real world logistic village location evaluation problem was solved. In this logistic village location evaluation problem there are 8 criteria and 11 candidate location including İstanbul (Halkalı), Balıkesir (Gökköy), Eskişehir (Hasanbey), İzmit (Köseköy), Uşak, Denizli (Kaklık), Samsun (Gelemen), Mersin (Yenice), Kayseri (Boğazköprü ), Konya (Kayacık) and Erzurum (Palandöken). The hierarchical structure to select the best logistic village location is shown in Fig 3. In order to identify weights of the criteria previous academic research done by Bamyac1 (2008) was used.

Criteria to be considered in the evaluation of logistic village location are determined by literature review. It was very hard to evaluate some of qualitative criteria. Therefore in this research just quantitative criteria were investigated. 8 important criteria to be used for logistic village location evaluation are established. These 8 criteria are as follows: "Initial size of the land" $(\mathrm{C} 1)$, "Cost of land" (C2), "Proximity to industrial zone" (C3), "Proximity to airport" (C4), "Proximity to harbor" 
(C5), "Proximity to railroad system" (C6), "Proximity to highway system" (C7) and "Effects on economy" (C8).

Figure 3. Hierarchical Structure for Logistic Village Evaluation

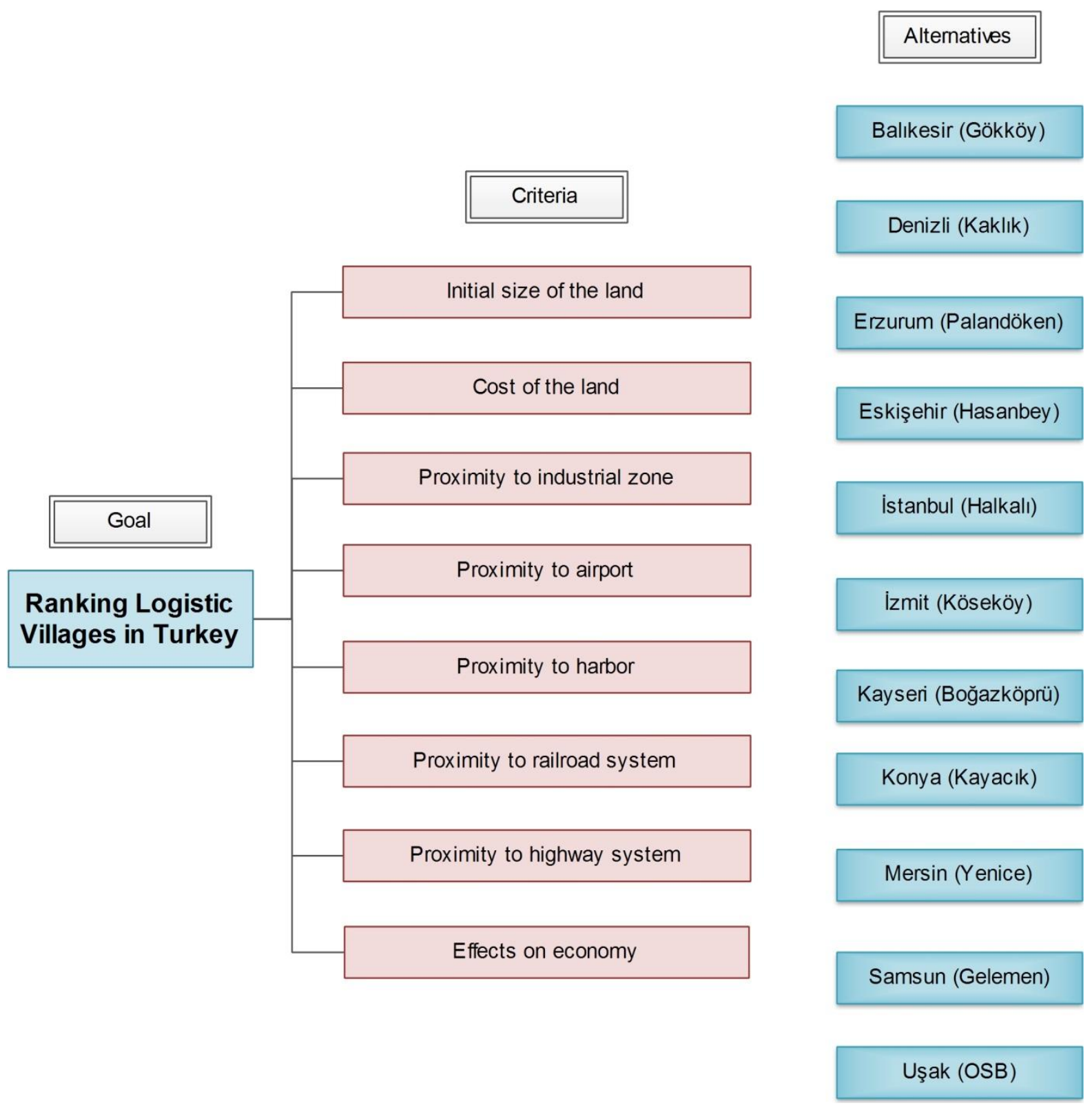

As a result, only these 8 criteria were used in evaluation and decision hierarchy is established accordingly. Decision hierarchy structured with the determined alternative logistic village locations and criteria is provided in Figure 3. There are three levels in the decision hierarchy structured for logistic village location evaluation problem. The overall goal of the decision process is "ranking logistic villages in Turkey" in the first level of the hierarchy. The criteria are on the second level and alternative locations are on the third level of the hierarchy. 
Figure 4. Location Alternatives of the Problem (Source: https://maps.google.com/)

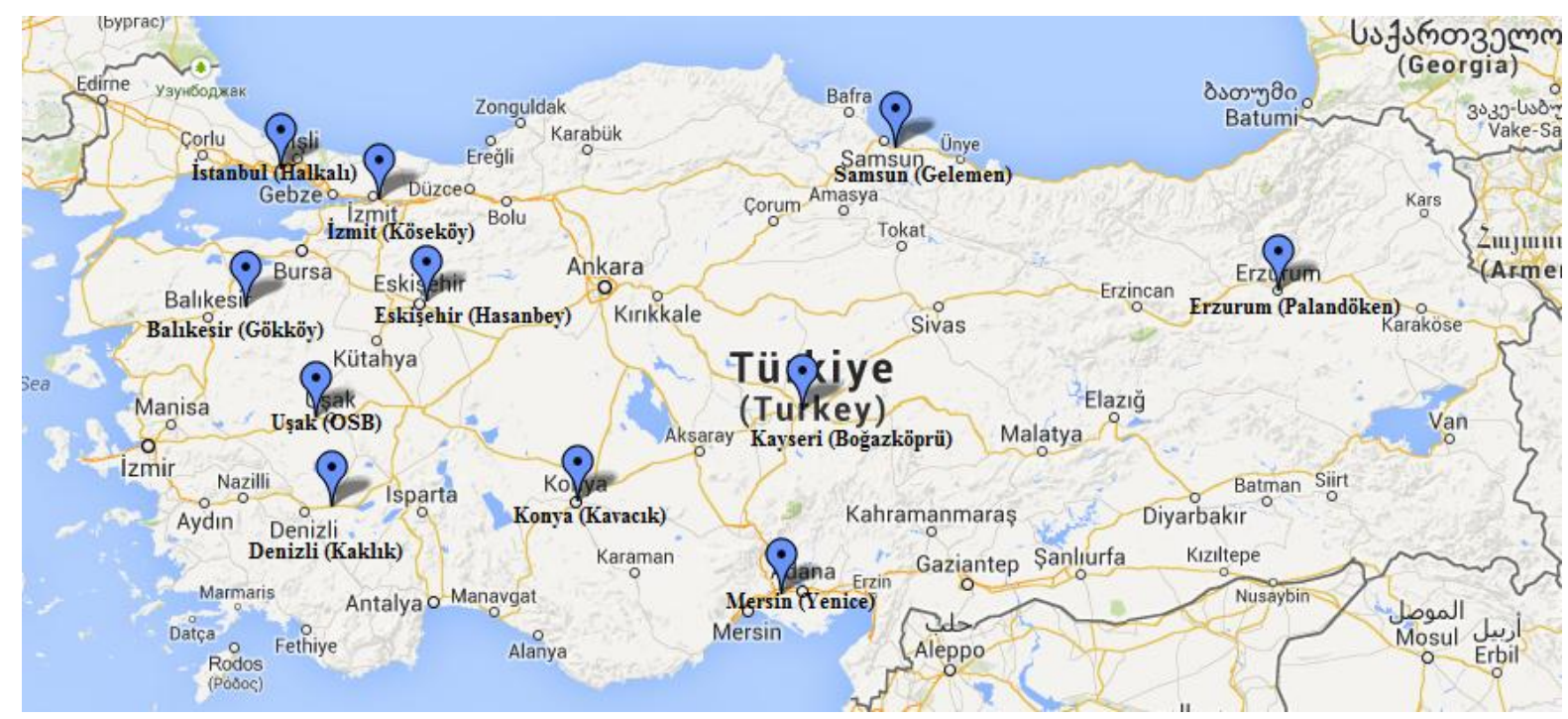

After forming the decision hierarchy for the problem, the weights of the criteria to be used in evaluation process are calculated by using AHP method. In this phase, the experts in the expert team are given the task of forming individual pairwise comparison matrix by using the Saaty's 1-9 scale.

Table 4. Weights Obtained Using AHP

\begin{tabular}{|c|c|}
\hline Criteria & Weights \\
\hline Initial size of the land & 0.106 \\
\hline Cost of land & 0.165 \\
\hline Proximity to industrial zone & 0.072 \\
\hline Proximity to airport & 0.034 \\
\hline Proximity to harbor & 0.158 \\
\hline Proximity to railroad system & 0.153 \\
\hline Proximity to highway system & 0.174 \\
\hline Effects on economy & 0.137 \\
\hline
\end{tabular}

Geometric means of experts' choice values are calculated to form the pairwise comparison matrix on which there is an agreement (Table 4). The results obtained from the calculations based on the pairwise comparison matrix are presented in Table 4. 


\section{Figure 5. Overall Resulting Weights of Criteria Obtained with AHP}

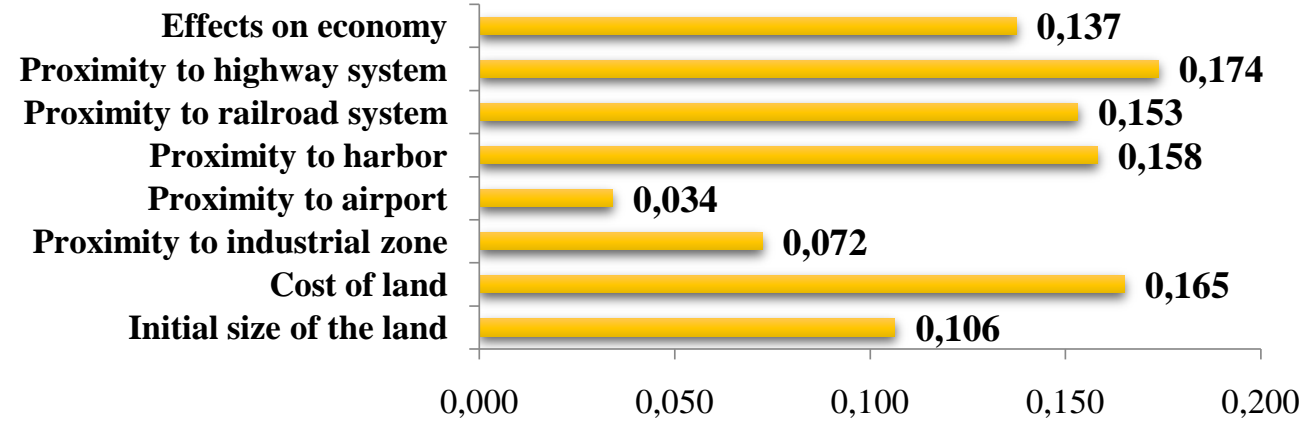

The "C7: Proximity to highway system" (0.174), "C2: Cost of land (0.165) and "C5: Proximity to harbor" $(0.158)$ are determined as the three most important criteria in the logistic village location selection process by using AHP (Figure 5). Consistency ratios of the experts' pairwise comparison matrixes are all less than 0.1. So the weights are shown to be consistent and they are used in the selection process. The most important criterion is "C7: Proximity to highway system" $(0.174)$ and the least important criterion is "C4: Proximity to airport" $(0.034)$.

Finally, VIKOR method is applied to rank the alternative locations. The priority weights of alternative locations with respect to criteria, calculated by AHP and shown in Figure 5, can be used as input of VIKOR (Table 5). The best and the worst values of all criterion functions are shown in Table 6.

Table 5. Input Values of the Vikor Analysis

\begin{tabular}{|c|c|c|c|c|c|c|c|c|}
\hline Weights & 0.106 & 0.165 & 0.072 & 0.034 & 0.158 & 0.153 & 0.174 & 0.137 \\
\hline Criteria & $\mathrm{C} 1$ & $\mathrm{C} 2$ & $\mathrm{C} 3$ & $\mathrm{C} 4$ & $\mathrm{C} 5$ & C6 & C7 & $\mathrm{C} 8$ \\
\hline Logistic Villages & $\begin{array}{l}\text { Meter } \\
\text { Square }\end{array}$ & Index & $\begin{array}{l}\text { Distance } \\
(\mathrm{KM})\end{array}$ & $\begin{array}{l}\text { Distance } \\
(\mathrm{KM})\end{array}$ & $\begin{array}{l}\text { Distance } \\
(\mathrm{KM})\end{array}$ & $\begin{array}{l}\text { Distance } \\
(\mathrm{KM})\end{array}$ & $\begin{array}{l}\text { Distance } \\
(\mathrm{KM})\end{array}$ & Ton/Year \\
\hline Balıkesir (Gökköy) & 200,000 & 0.48 & 68.4 & 53 & 98.6 & 54.3 & 33 & 390,000 \\
\hline Denizli (Kaklık) & 300,000 & 0.7 & 16.5 & 31.5 & 264 & 32.6 & 0.8 & 634,000 \\
\hline Erzurum & 327,000 & 0.1 & 11 & 13.7 & 325 & 2.2 & 1 & 200,000 \\
\hline Eskişehir (Hasanbey) & 630,000 & 0.7 & 9.5 & 10.2 & 188 & 8.6 & 5.6 & 215,000 \\
\hline İstanbul (Halkalı) & $1,060,0$ & 2.65 & 6.6 & 9.6 & 21.4 & 3.5 & 3.2 & 944,000 \\
\hline İzmit (Köseköy) & 765,000 & 2.1 & 44.2 & 18.3 & 17.2 & 26 & 1.1 & 600,000 \\
\hline Kayseri & 511,000 & 0.06 & 6.8 & 25.8 & 320 & 74.9 & 0.6 & 717,000 \\
\hline Konya (Kayacık) & 120,000 & 0.57 & 19.2 & 16.9 & 323 & 2.1 & 4.5 & 150,000 \\
\hline Mersin (Yenice) & 640,000 & 0.89 & 26.6 & 25.4 & 61 & 63.2 & 0.85 & 418,000 \\
\hline Samsun (Gelemen) & 333,000 & 0.55 & 7.5 & 5.3 & 16.6 & 19.1 & 0.5 & 500,000 \\
\hline Uşak (OSB) & 140,000 & 0.32 & 1 & 23.9 & 198 & 18 & 1.7 & 113,000 \\
\hline
\end{tabular}


Table 6. The Best $f_{i}^{*}$ and the Worst $f_{i}^{-}$Values of All Criterion Functions

\begin{tabular}{|c|c|c|c|c|}
\hline \multicolumn{2}{|c|}{ Criteria } & \multirow{2}{*}{$\frac{\text { Effect }}{+}$} & \multirow{2}{*}{$\begin{array}{l}f_{i}^{*} \text { (Best Value) } \\
1,060,000\end{array}$} & \multirow{2}{*}{$\begin{array}{l}f_{i}^{-} \text {(Worst Value) } \\
120,000\end{array}$} \\
\hline $\mathrm{C} 1$ & Initial size of the land & & & \\
\hline $\mathrm{C} 2$ & Cost of land & - & 0.06 & 2.65 \\
\hline $\mathrm{C} 3$ & Proximity to industrial zone & - & 1.00 & 68.40 \\
\hline $\mathrm{C} 4$ & Proximity to airport & - & 5.30 & 53.00 \\
\hline $\mathrm{C} 5$ & Proximity to harbor & - & 16.60 & 325.00 \\
\hline C6 & Proximity to railroad system & - & 2.10 & 74.90 \\
\hline $\mathrm{C} 7$ & Proximity to highway system & - & 0.50 & 33.00 \\
\hline & Effects on economy & + & 944,000 & 113,000 \\
\hline
\end{tabular}

Table 7. Calculation of Si and Ri for Criteria

\begin{tabular}{lllllllll}
\hline & C1 & C2 & C3 & C4 & C5 & C6 & C7 & C8 \\
\hline S1 & 0.097 & 0.027 & 0.072 & 0.034 & 0.042 & 0.110 & 0.174 & 0.092 \\
S2 & 0.086 & 0.041 & 0.017 & 0.019 & 0.127 & 0.064 & 0.002 & 0.051 \\
S3 & 0.083 & 0.003 & 0.011 & 0.006 & 0.158 & 0.000 & 0.003 & 0.123 \\
S4 & 0.049 & 0.041 & 0.009 & 0.003 & 0.088 & 0.014 & 0.027 & 0.120 \\
S5 & 0.000 & 0.165 & 0.006 & 0.003 & 0.002 & 0.003 & 0.014 & 0.000 \\
S6 & 0.033 & 0.130 & 0.046 & 0.009 & 0.000 & 0.050 & 0.003 & 0.057 \\
S7 & 0.062 & 0.000 & 0.006 & 0.015 & 0.156 & 0.153 & 0.001 & 0.038 \\
S8 & 0.106 & 0.033 & 0.020 & 0.008 & 0.157 & 0.000 & 0.021 & 0.131 \\
S9 & 0.048 & 0.053 & 0.027 & 0.014 & 0.023 & 0.129 & 0.002 & 0.087 \\
S10 & 0.082 & 0.031 & 0.007 & 0.000 & 0.000 & 0.036 & 0.000 & 0.073 \\
S11 & 0.104 & 0.017 & 0.000 & 0.013 & 0.093 & 0.033 & 0.006 & 0.137 \\
\hline
\end{tabular}

By using VIKOR method, the ranking of alternative locations are calculated. With using Eq. 12 and Eq. 13, we can obtain $S^{*}=0.194, S^{-}=0.647, R^{*}=0.082, R^{-}=0.174$. Table 8 shows the evaluation results and final ranking of alternative logistic villages.

Table 8. Calculation of Si and Ri for Criteria

\begin{tabular}{lllllll}
\hline Logistic Villages & $S j$ & Rank & $R j$ & Rank & $Q j(v=0,5)$ & Rank \\
\hline Samsun (Gelemen) & 0.230 & $\mathbf{2}$ & 0.082 & $\mathbf{1}$ & 0.039 & $\mathbf{1}$ \\
Eskişehir (Hasanbey) & 0.351 & 4 & 0.120 & $\mathbf{2}$ & 0.383 & $\mathbf{2}$ \\
İzmit (Köseköy) & 0.330 & $\mathbf{3}$ & 0.130 & 5 & 0.411 & $\mathbf{3}$ \\
İstanbul (Halkalı) & 0.194 & 1 & 0.165 & 10 & 0.453 & 4 \\
Mersin (Yenice) & 0.382 & $\mathbf{5}$ & 0.129 & 4 & 0.461 & $\mathbf{5}$ \\
Denizli (Kaklık) & 0.406 & 8 & 0.127 & 3 & 0.477 & 6 \\
Uşak (OSB) & 0.404 & $\mathbf{7}$ & 0.137 & 6 & 0.533 & $\mathbf{7}$ \\
Erzurum & 0.386 & 6 & 0.158 & 9 & 0.627 & 8 \\
Kayseri & 0.430 & 9 & 0.156 & 7 & 0.661 & 9 \\
Konya (Kayac1k) & 0.476 & $\mathbf{1 0}$ & 0.157 & 8 & 0.720 & $\mathbf{1 0}$ \\
Balıkesir (Gökköy) & 0.647 & $\mathbf{1 1}$ & 0.174 & $\mathbf{1 1}$ & 1.000 & $\mathbf{1 1}$ \\
\hline
\end{tabular}

C1. Acceptable Advantage: 


$$
\begin{aligned}
& D Q=1 /(11-1)=0.1 \\
& Q\left(a^{\prime \prime}\right)-Q\left(a^{\prime}\right) \geq D Q \rightarrow(0.383-0.039) \geq 0.1 \rightarrow 0.344 \geq 0.1
\end{aligned}
$$

but $Q\left(a^{\prime \prime \prime}\right)-Q\left(a^{\prime \prime}\right) \geq D Q \rightarrow(0.411-0.383)<0.1$ therefore the positions of Eskişehir (Hasanbey) and İzmit (Köseköy) alternatives are "in closeness".

\section{C2. Acceptable stability in decision making:}

Alternative Samsun (Gelemen) is in the best ranked by $Q$ and $R$. This compromise solution is stable within a decision making process, by consensus.

Depends on the $\mathrm{RCj}$ values, the ranking of the first three alternatives from top to bottom order are Samsun (Gelemen), Eskişehir (Hasanbey), İzmit (Köseköy) (Table 9). Proposed model results show that Samsun (Gelemen) is the best alternative with Qj value. Decision team can also investigate the other two alternatives Eskişehir (Hasanbey), İzmit (Köseköy) one more time. The positions of these two alternatives are close in VIKOR method. Depends on the analysis the least suitable logistic village is Balıkesir (Gökköy).

Table 9.VIKOR Rankings

\begin{tabular}{lll}
\hline Logistic Villages & $Q j(v=0,5)$ & Rank \\
\hline Samsun (Gelemen) & 0.039 & 1 \\
Eskişehir (Hasanbey) & 0.383 & 2 \\
İzmit (Köseköy) & 0.411 & 3 \\
İstanbul (Halkalı) & 0.453 & 4 \\
Mersin (Yenice) & 0.461 & 5 \\
Denizli (Kaklı) & 0.477 & 6 \\
Uşak (OSB) & 0.533 & 7 \\
Erzurum (Palandöken) & 0.627 & 8 \\
Kayseri (Boğazköprü) & 0.661 & 9 \\
Konya (Kayacık) & 0.720 & 10 \\
Balıkesir (Gökköy) & 1.000 & 11 \\
\hline
\end{tabular}

\section{CONCLUSION AND SUGGESTIONS}

Logistic village location decisions are very important part in any countries' overall strategic plan. There should be more planning activities, efforts and long-term policy of logistic villages in Turkey. By using multi criteria decision techniques on logistic sector problems energy consumption can be minimized. In Turkey logistic costs still is a big part of the total product costs for firms due to energy prices. Increase the efficiency of logistics by using quantitative techniques also would decrease 
traffic load in the urban areas and increase the performance of a logistics firms. Total traffic can be reduced by choosing correct location of logistic villages. It is important to analyze the criteria affecting government' logistic village location choices. Making direct road and rail access, creating highly developed infrastructure, avoiding traffic in urban area, reducing carbon-dioxide and noise, decreasing total transport costs would be useful conclusions of affective analyses of optimum logistic villages' locations.

This paper presents a multi-criteria decision model for evaluating alternatives of logistic villages. For this purpose, a two-step methodology is introduced, in which the AHP emphasizes the most meaningful criteria via expertise of decision making team members. Then, VIKOR method applies AHP' weights as input weights. Finally, logistic village location problem was solved by using proposed method to show applicability and performance of the proposed methodology. By the compromise ranking method, the compromise solution is determined which would be most acceptable to the decision makers because it provides a maximum "group utility" for the "majority", and a minimum of individual regret for the "opponents". In next studies analytic network process (ANP) may be used to structure network and identify dependence among criteria. The proposed methodology can also be applied to any other selection problem involving multiple and conflicting criteria. Selection of the logistic village location can also be done using other MCDM techniques for comparing the results.

The literature on quantitative decision making of logistic villages is relatively limited. There should be more research papers. In future researches more criteria including opportunities for possible site expansion, infrastructure of the land, physical conditions of the land, environmental factors, effects on traffic etc. can be analyzed in order to rank logistic villages. But generally it is hard to find all data related with these criteria in Turkish logistic sector.

\section{REFERENCES}

Awasthi, A., Chauhan, S.S. and Goyal, S.K., (2011). A multi-criteria decision making approach for location planning for urban distribution centers under uncertainty, Mathematical and Computer Modelling, 53, 98-109

Ballis, A. and Mavrotas, G., (2007). Freight village design using the multicriteria method PROMETHEE.Operational Research. An International Journal, Vol. 7, No. 2, pp. 213-232

Bamyaci, M., (2008). "Modern Lojistik Yönetimi: Organize Lojistik Bölgeleri İçin Bir Yer Seçimi Modeli” Istanbul Universitesi, Fen Bilimleri Enstitusu, Doktora Tezi, In Turkish.

Cavallini, C., Giorgetti, A., Citti, P. and Nicolaie, F., (2013). Integral aided method for material selection based on quality function deployment and comprehensive VIKOR algorithm, Materials and Design 47, 27-34 
Cerreno, A. L. C., Shin, H., S., Wieder, A.S. and Theofanis, S., (2008). Feasibility of Freight Villages in the New York Metropolitan Transportation Council (NYMTC) Region, Center for Advanced Infrastructure and Transportation Freight and Maritime Program, 1-23

Chen, L.Y. and Wang, T.C., (2009). Optimizing partners' choice in IS/IT outsourcing projects: The strategic decision of fuzzy VIKOR, Int. J. Production Economics 120, 233-242

Chiu, W. Y., Tzeng, G. H. and Li, H.L., (2013). A new hybrid MCDM model combining DANP with VIKOR to improve e-store business, Knowledge-Based Systems 37, 48-61

Cristobal, J.R.S., (2011). Multi-criteria decision- making in the selection of a renewable energy project in spain: The Vikor method, Renewable Energy 36, 498-502

Dagdeviren, M., Yavuz, S. and Kilinc, N., (2009). Weapon selection using the AHP and TOPSIS methods under fuzzy environment, Expert Systems with Applications, 36, 8143-8151

Ertuğrul, İ and Karakaşoğlu, N., (2008). Comparison of fuzzy AHP and fuzzy TOPSIS methods for facility location selection, International Journal of Advanced Manufacturing Technology, vol.39, no.7, pp.783-795.

Girubha, R.J. and Vinodh, S., (2012). Application of fuzzy VIKOR and environmental impact analysis for material selection of an automotive component, Materials and Design 37, 478-486

Hsu C.H., Wang, F.K. and Tzeng, G.H., (2012). The best vendor selection for conducting the recycled material based on a hybrid MCDM model combining DANP with VIKOR, Resources, Conservation and Recycling, 66, 95- 111.

http://ekonomi.haber7.com/ekonomi/haber/466883-turkiyenin-arazisi-en-pahali-ili-hangisi-27.08.2013

http://www.moment-expo.com/turkiyede-lojistik-koyler-kuruluyor - 21.08.2013

http://web.itu.edu.tr/oguts/Avrupada\%20ve\%20T\%FCrkiyede\%20lojistik\%20k\%F6yler.PDF

Working Paper: Aydın G. T., Ögüt K. S “Freight villages in Europe and Turkey?” -25.08.2013

https://maps.google.com/ -29.08.2013

Jahan, A., Mustapha, F., Ismail, M.Y., Sapuan, S.M. and Bahraminasab, M., (2011). A comprehensive VIKOR method for material selection, Materials and Design 32, 1215-1221.

Janic, M. and Reggiani, A., (2002). An Application of the Multiple Criteria Decision Making (MCDM) Analysis to the Selection of a New Hub Airport, EJTIR, 2, no. 2, pp. 113 - 141 
Jaržemskis, A., (2007). Research on Public Logistics Centre as Tool for Cooperation, Transport, Vol XXII, No 1, 50-54

Kuo, M.S. and Liang, G.S., (2011). Combining VIKOR with GRA techniques to evaluate service quality of airports under fuzzy environment Expert Systems with Applications 38, 1304-1312

Lee, S., Kim, W., Kim, Y.M. and Oh, K.J., (2012). Using AHP to determine intangible priority factors for technology transfer adoption. Expert Systems with Applications, 39, 6388-6395.

Li, Y., Liu, X. and Chen, Y., (2011). Selection of logistics center location using Axiomatic Fuzzy Set and TOPSIS methodology in logistics management, Expert Systems with Applications 38, 7901-7908

Liberatore, M.J. and Nydick, R.L., (1997). Group Decision Making In Higher Education Using the Analytic Hierarchy Process, Research in Higher Education, Vol. 38, No. 5

Lindholm, M. and Behrends, S., (2012). Challenges in urban freight transport planning - a review in the Baltic Sea Region, Journal of Transport Geography 22, 129-136

Liu, C.H., Tzeng, G.H. and Lee, M.H., (2012). Improving tourism policy implementation: The use of hybrid MCDM models, Tourism Management 33, 413-426

Liu, C.H., Tzeng, G.H., Lee, M.H. and Lee, P.Y., (2013). Improving metro-airport connection service for tourism development: Using hybrid MCDM models, Tourism Management Perspectives 6, 95-107

Liu, H.C., Mao, L.X., Zhang, Z.Y. and Li, P., (2013). Induced aggregation operators in the VIKOR method and its application in material selection, Applied Mathematical Modelling 37, 63256338

Opricovic, S., (2011). Fuzzy VIKOR with an application to water resources planning, Expert Systems with Applications, 38, 12983-12990

Opricovic, S. and Tzeng, G.H., (2002). Multicriteria planning of post-earthquake sustainable reconstruction.The Journal of Computer-Aided Civil and Infrastructure Engineering 17 (3), 211-220.

Opricovic, S. and Tzeng, G.H., (2004). Compromise solution by MCDM methods: A comparative analysis of VIKO R and TOPSIS, European Journal of Operational Research, 156, 445-455 
Opricovic, S. and Tzeng, G.H., (2007). Extended VIKOR method in comparison with outranking methods, European Journal of Operational Research, 178, 514-529

Saaty, T.L., (1980). The analytic hierarchy process. New York: McGraw-Hill.

Saaty, T. L. and Vargas Luis L., (2001). Models, Methods, Concepts\& Applications of the Analytic Hierarchy Process. International Series in Operations Research \& Management Science, Kluwer Academic Publishers.

Saaty, T. L., (2008). Decision Making With the Analytic Hierarchy Process. Int. J. Services Sciences, $1(1), 83$.

Saaty, T.L., (1990). How To Make Decision: The Analytic Hierarchy Process, European Journal of Operational Research,North_Holland, 48, 9-26

Sanayei, A., Mousavi, S.F. and Yazdankhah, A, (2010). Group decision making process for supplier selection with VIKOR under fuzzy environment, Expert Systems with Applications 37, 24-30

Shemshadi, A., Shirazi, H., Toreihi, M. and Tarokh, M.J., (2011). A fuzzy VIKOR method for supplier selection based on entropy measure for objective weighting, Expert Systems with Applications 38, 12160-12167

Sirikijpanichkul, A. and Ferreira, L., (2006). Solving the Conflicts in Intermodal Freight Hub Location Decisions, BEE Postgraduate Infrastructure Theme Conference, 26th September 2006, Gardens Point Campus, Queensland University of Technology

Taniguchi, E., Noritake, M., Yamada, T. and Izumitani, T., (1999). Optimal size and location planning of public logistics terminals, Transportation Research Part E 35, 207-222

Tsai, W.H, Chou, W.C. and Leu, J.D., (2011). An effectiveness evaluation model for the web-based marketing of the airline industry, Expert Systems with Applications, 38, 15499-15516

Tzeng, G.H., Lin, C.W. and Opricovic, S., (2005). Multi-criteria analysis of alternative-fuel buses for public transportation, Energy Policy, 33, 1373-1383

Tzeng, GH, Teng, MH, Chen, JJ and Opricovic, S, (2002). Multi-criteria selection for a restaurant location in Taipei, International Journal of Hospitality Management, vol. 21, no: 2, pp. 171-187

Wang, Y.L. and Tzeng, G.H., (2012). Brand marketing for creating brand value based on a MCDM model combining DEMATEL with ANP and VIKOR methods, Expert Systems with Applications 39, 5600-5615 
Yalçın, N., Bayrakdaroğlu A. and Kahraman, C., (2012). Application of fuzzy multi-criteria decision making methods for financial performance evaluation of Turkish manufacturing industries, Expert Systems with Applications 39, 350-364

Yanga, L., Jib, X.,Gaoa, Z. and Li, K., (2007). Logistics distribution centers location problem and algorithm under fuzzy environment, Journal of Computational and Applied Mathematics 208, $303-315$

Yoo, K.E. and Choi, Y.C., (2006). Analytic Hierarchy Process Approach For Identifying Relative Importance Of Factors To Improve Passenger Security Checks At Airports, Journal of Air Transport Management 12, 135-142

Yücenur, G.N. and Demirel, N.Ç., (2012). Group decision making process for insurance company selection problem with extended VIKOR method under fuzzy environment, Expert Systems with Applications 39, 3702-3707

Zhang, N. and Wei, G., (2013). Extension of VIKOR method for decision making problem based on hesitant fuzzy set. Applied Mathematical Modelling 37, 4938-4947. 